\title{
Stasis: Civil War as a Political Paradigm, by Giorgio Agamben
}

Homo Sacer II, 2 | Translated by Nicholas Heron | Stanford: Stanford University Press, $2015 \mid 96$ pages | ISBN: 978-0-80479605-7 (hardcover) \$50.00 | ISBN: 978-0-804-7973 I-3 (softcover) \$I . I 5

The Homo Sacer series continues to throw up surprises. In 2014 after nine books and almost three decades the Italian philosopher Giorgio Agamben decided to bring the series to an end by abandoning it in one last attempt to rethink the "originary structure of Western politics" in religion, biology, sovereignty and economics. ${ }^{1}$ Perhaps most intriguing in the series however is the belated appearance in 2015 of Stasis: Civil War as a Political Paradigm. ${ }^{2}$ A very small volume based on two seminars given by Agamben at Princeton University in 200I shortly after the attacks on the World Trade Centre, Stasis has historical significance. Almost immediately translated into English and French, its appearance also altered the entire order of the Homo Sacer series. Stasis is positioned as something of a threshold or bridge between dimensions, between Agamben's early focus on the relationship between politics and life, further digging into law and civil war in State of Exception (2003), and his later exploration of economics and theology. Agamben's decision to publish Stasis may invite back some of the excitement that followed in the wake of Homo Sacer: Sovereign Power and Bare Life (1995). Whether the book achieves the same feat as Homo Sacer is questionable. It is however at its best when it delves into the relationship between religion and politics.

Never directly confronting the growing phenomenon of global terrorism, Agamben argues in Stasis that the response to terrorism is based on the essential character of modern Western politics: "The form that civil war

${ }^{1}$ Giorgio Agamben, The Use of Bodies, Homo Sacer IV, 2; trans. Adam Kotsko (Stanford: Stanford University Press, 2015 ), 263. The Use of Bodies was originally published in Italian in 2014 under the title L'uso dei corpi.

${ }^{2}$ Stasis was originally published in Italian in 20 I 5 under the title Stasis: La Guerra civile come paradigm politico (Torino: Bollati Boringhieri). In French Stasis was curiously translated as La guerre civile: pour une théorie politique de la stasis, trans. Joel Gayraud (Paris: Points, 2015). 
has acquired today in world history is terrorism" (24). Agamben develops a link here to terrorism in a somewhat disappointingly sketchy thesis that modern politics is continuous with a biopolitics that has a genealogy in "an oikonomika-theological paradigm" (24). The current struggle between religion and politics would nonetheless appear to bear out this analysis of a globalisation of various economic, theological and political zones of distinction and indistinction. Agamben however does not focus clearly on the "fields of tension" that have emerged, and the polarisation of his argument forces us to speculate about terrorism as a kind of antithesis of modern liberal politics (19). There is a great degree of miltonic obscurity in this context; nonetheless, it is the interplay between religion and politics, in the various threshold forms of life, spaces and economies, that is tracked in Stasis. These connections are also provocations, as they expose Agamben's "Western politics" to some unsettling contexts.

Two moments in Stasis in particular capture the manner of Agamben's provocations. Agamben claims that "today" —of all times- "there is no 'stasiology,' no theory of civil war" (2). This follows the argument of the German jurist and political scientist Roman Schnur, who suggests that the advance of a "global civil war" goes hand-in-hand with a certain kind of "disregard" for civil war itself (I). Just as in State of Exception, published in 2003, Agamben points to the contemporaneous emergence of the concept of "global civil war" in 1963 in the writings of Carl Schmitt and Hannah Arendt as a kind of discourse marker for theorising about the loss of traditional forms of war. Agamben suggests that theories of civil war in the twentieth century have been absorbed by "the absolute space of global economic management" (8). This is at once scathing about liberal politics and imprecise. In another provocation, Agamben notes that there is in general confusion between theories of revolution and civil war. Hannah Arendt in On Revolution may have distinguished the concepts of civil war and revolution, but Agamben departs from his mentor to claim: "it is likely that the difference between the two concepts is in fact purely nominal" (3). This provocation is casually aimed at the entire tradition of Italian Marxism. ${ }^{3}$

Related to these controversial positions is Agamben's choice to draw on the Greek word stasis, which implies a number of different meanings not all

${ }^{3}$ Something that is designed to stir up the responses of Albert Toscano, Michel Hardt and Antonio Negri. Toscano has already taken the bait in his Stanford University Press blog review of Agamben's Stasis, "Giorgio Agamben's Political Paradigm. Notes on Stasis," http://stanfordpress.typepad.com/blog/20 I 6/o7/giorgio-agambens-political-paradigm.html. 
of which are explored in Stasis. The only direct definition that Agamben gives is in reference to the ancient Greek theatrical tradition: "the act of rising, of standing firmly upright" (where "stasimos is the point in the tragedy when the chorus stands still and speaks," I3-I4). A stasimon ( $\sigma \tau \dot{\alpha} \sigma \mu \rho \nu)$ is a stationary ode directed at a moment in a tragedy: a blurring of definition between political history and theatre that suggests something of the oddly both productive and indistinct value that Agamben gives to civil war. Agamben draws on the infamous seventeenth-century English political philosopher Thomas Hobbes's translation of Thucydides's Histories, but does not refer to the fact that the Greek word stasis is translated by Hobbes as sedition: stasis is obviously aimed at sovereign power, which must be able to move across the land and seas. ${ }^{4}$ Preventing civil war has usually been read as the project of Hobbes's Leviathan, ${ }^{5}$ and arguably of liberalism in political philosophy as a whole that attempts to shift the location of politics from sovereignty to civil development. But one of the most Foucauldian dimensions of Agamben's approach is to consider the link between the management of civil war and ademia (the absence of people), a clearing of the way that has its own biopolitics and is a logical result of establishing the negation of stasis as an economic and political goal.

In its investigation of the catastrophe of civil war, Stasis is divided into two chapters, "Stasis," which divines an unstable political paradigm with reference to the Greek tradition, and "Leviathan and Behemoth," which in iconography alone has the burden of showing the emergence of a modern biopolitics of civil war in Thomas Hobbes. These chapters move the reader into an interesting threshold that is located between homes, cities, churches

${ }^{4}$ One of Agamben's critics, Dimitris Vardoulakis, points out this detail in Hobbes's translation of Thucydides; Agamben himself does not mention it. Agamben's reading of the iconography of Hobbes's Leviathan is obviously relevant to the translation of stasis in Thucydides and also draws on the biopolitical resonances of the translation. See Dimitris Vardoulakis, "The Ends of Stasis: Spinoza as a Reader of Agamben," The Politics of Nothing: On Sovereignty, ed. Clare Monagle and Dimitris Vardoulakis (Abingdon and New York: Routledge and Taylor \& Francis, 2013), 37-50.

${ }^{5}$ Agamben's reading of Hobbes's iconography in Stasis follows but does not acknowledge the arguments laid out by Quentin Skinner, "Hobbes and the Purely Artificial Person of the State," The Journal of Political Philosophy 7, no. I (I999): I-29. His reading of civil war in Hobbes is also generally a commonplace and old one: "The philosophy of Hobbes, therefore, is not dangerous in any government; its sole aim is to preserve it from intestine divisions; but for this purpose, he was for reducing men to mere machines." See Isaac D'Israeli, Quarrels of Authors; or, Some Memoirs for our Literary History, Including Specimens of Controversy to the Reign of Elizabeth, by the Author of "Calamities of Authors", Vol. III (London: John Murray, I8I4), 26. 
and people. What is exposed in these chapters is the extent to which politics is located in sites other than parliament, monarchy or states. One outcome of this othering of politics is to show an intimate relationship between sovereignty and civil war, in which the latter is something of a nuisance. ${ }^{6}$ Throughout Stasis, Agamben is at pains to show that civil war is a disreputable concept or object of study. It is not quite middle class to dwell on civil war, much in the way that the Marxist concept of class warfare has become disreputable. The first chapter of Stasis therefore begins with a provocative statement that "a theory of civil war is completely lacking today" (I). This statement is "curious," even "to the point of being spurious," as Jacques Derrida would have put it. ${ }^{7}$ But it does alert the reader to the low value of civil war within philosophies that may be closer to power politics than we tend to acknowledge. ${ }^{8}$ This is obviously another missive fired at the liberal tradition of political philosophy, with its long history of contract theory and natural law: "specialists continue to carefully avoid any hint at a theory of civil war" (I).

On a housekeeping front, the translation of Stasis is reliable. If one were to find a nuisance it would be the occasionally unsophisticated lapses into colloquial or informal English that fail to register clear nuances. ${ }^{9}$ Of course, given Agamben's circular and obscure language the translator's temptation to bring less ponderous speech into the translation is understandable. Some of the drawbacks in Agamben's management of his own book do risk modifying our appreciation of its success. The elliptical writing as we have said does not

${ }^{6}$ At this point in Stasis, the value of bringing in the precedent of ancient Greece is surely to help Agamben rediscover the conceptual "robbers, fleas, and dogs" of history that are, as Thomas De Quincey put it, "respectable nuisances [...] of classical descent." See Thomas De Quincey "Modern Greece", Logic of Political Economy and Other Papers (Edinburgh: Adam and Charles Black, I 863), 453. This essay was published in Blackwood's Magazine (July I 842).

${ }^{7}$ Jacques Derrida, The Beast and the Sovereign, vol. I, trans. Geoffrey Bennington (Chicago: University of Chicago Press, 2009), 53.

${ }^{8}$ Immanuel Kant in Toward a Perpetual Peace (1795) characterised liberal republicanism as a statist progression from a state of nature to a state of peace, and it is this tradition that is indirectly confronted by Agamben in Stasis: "the very possibility of distinguishing a war between States and internecine war appears today to have disappeared." Agamben, Stasis, I.

${ }^{9}$ Examples of this are: the opening sentence of chapter I manages to lose some of the elegance of Agamben's already stagnant prose, somehow even becoming a little snider in its context when the word "troppo" is translated literally as "too much" and falls at the end of the sentence. In the very short forward, the translation of "I lettori decideranno" as "It is up to the readers to determine" is noticeable for the way in which it avoids the word "decision", which actually resonates much more clearly with Agamben's theories of sovereignty. Agamben, Stasis, ix, I. 
assist even the "alert readers" who are "capable of not allowing the particular details and modalities of the exposition to escape them" (29). There is in addition Agamben's ungenerous and frustrating tendency to present his work as being "twice first, the first to see and announce, and the first to remind." 10 Finally, Agamben's refusal to be direct in examining historical and philosophical context is always unhelpful, and the genealogical and paradigmatic methods that Agamben favours unhelpfully locate periods without examining how assumptions about modernity itself are tied up in the machine of Western politics that Agamben claims to be bringing to a halt. ${ }^{11}$

We are asked by the foreword that begins Stasis to consider if the "theses" of the book reveal something "essential" about Western politics in its historical passage into global civil war (ix). Stasis does not arguably provide anything new to say about terrorism and civil war, but the theses of Stasis are provocations aimed at challenging the foundations of politics in general. The most exciting feature of Stasis is that it does investigate-much too elliptically for any reader's good-the political and religious dimensions of life, economics, and space. Read in this way, Stasis does tell its reader something essential about the set of circumstances the world finds itself in today. It is not a reassuring grasp on politics: what is presented is a kind of global critical stasis in liberal ideology and in almost all other major political platforms. We are reminded almost daily that this is the new drama of contemporary Western politics. The staging of this drama of religion, politics and global civil war in what Agamben calls, if too casually, "Western politics" is perhaps the most satisfying aspect of Stasis. The work's publication is a slim but powerful bridge in the Homo Sacer series between the early political theories and the later theological speculations. With this provocation of this work, an alert reader is held in abeyance and can make the most of Agamben's own stasis to find new ways to stand and interrupt the chorus.

\section{Beornn McCarthy \\ University of Melbourne}

${ }^{10}$ As Derrida put it pointedly in The Beast and the Sovereign, 330. The confrontation between Agamben and Derrida is perhaps one of the interesting subterranean aspects to Stasis, which is based on seminars given almost at the same time as Derrida's seminars published in The Beast and the Sovereign. The relation of these two influential philosophers is something of an understated but ongoing civil war in continental philosophy

${ }^{11}$ As Bruno Latour and others have pointed out. Bruno Latour, We Have Never Been Modern, trans. Catherine Porter (Cambridge, MA: Harvard University Press, I993). Originally published as Nous n'avons jamais été modernes: Essais d'anthropologie symmétrique (I99I). 